\title{
Sublethal and histopathological effects of trace levels of tributyltin fluoride on adult oysters Crassostrea gigas
}

\author{
Dominique Chagot $^{(1)}$, Claude Alzieu ${ }^{(2)}$, Jane Sanjuan ${ }^{(2)}$ and Henri Grizel ${ }^{(1)}$ \\ (1) IFREMER, BP I33, I739o La Tremblade, France. \\ (2) IFREMER, Département Milieu et Ressources, BP Io49, 44037 Nantes Cedex oI, France.
}

Received October 4, I989; accepted March I, I990.

\begin{abstract}
Shell malformations and histological effects of environmental concentrations of TBTF (2, 13.1 and $64.8 \mathrm{ng} / \mathrm{l})$ were assessed on adult oysters Crassostrea gigas during a 1-month experiment, including both an exposure and a depuration phase. The results showed that the digestive gland is the primary target organ. Recoverable modifications were observed at the lowest concentration. Limited necrosis was observed at the highest concentration and a longer exposure could have led to extensive and irreversible tissue lesions. Shell malformations (chambering) were observed during the depuration phase. Finally the authors suggest that safe TBT levels in mariculture waters should be lower than $2 \mathrm{ng} / 1$.
\end{abstract}

Chagot D., C. Alzieu, J. Sanjuan, H. Grizel. Aquat. Living Resour., 1990, 3, 121-130.

Keywords : Tributyltin, Crassostrea gigas, histopathological effects.

Titre français à venir.

Résumé

Les malformations des coquilles et les effets histologiques du TBTF à des concentrations rencontrées dans l'environnement $(2,13.1$ et $64.8 \mathrm{ng} / 1)$ ont été évalués lors d'une expérimentation ayant duré 1 mois et comportant une phase d'exposition et une phase en eau non contaminée. Les résultats montrent que les diverticules digestifs sont les organes cibles primaires. Des modifications réversibles ont été observées à la plus faible concentration. Des nécroses partielles ont été observées à la plus forte concentration et une plus longue exposition aurait pu occasionner des lésions tissulaires étendues et irréversibles. Des malformations des coquilles (chambrage) ont été observées pendant la phase en eau non contaminée. Finalement, les auteurs suggèrent que les teneurs en TBT admissibles dans les eaux conchylicoles devraient être inférieures à $2 \mathrm{ng} / \mathrm{l}$.

Mots-clés : Tributylétain, Crassostrea gigas, effets histopathologiques.

Tributyltin (TBT) is widely used as antifoulant in paints for protection of hulls and other immersed surfaces. Consequently, increasing quantities of TBT have been introduced into marine coastal waters. In France, as early as 1981, TBT contamination of oyster culture areas has been strongly suspected of having deleterious effects on reproduction and growth of Pacific oysters Crassostrea gigas. It has now been shown clearly that tributyltins are highly toxic for marine molluses:
- larval development of $C$. gigas is affected when seawater contamination is higher than $20 \mathrm{ng} / 1$ (His and Robert, 1983, 1985);

- anomalies of calcification (thickening) have been experimentally produced at levels as low as $20 \mathrm{ng} / 1$ (Gendron, 1985) and field correlations observed between TBT contamination and frequency of C. gigas shell anomalies (Alzieu et al., 1989);

- decline in populations of the gastropod Nucella lapillus associated with imposex has been observed at 
TBT concentrations lower than $1 \mathrm{ng} / 1$ (Gibbs and Bryan, 1986).

In contrast, few data are available on histopathological effects of TBT on molluscs. Tissue lesions have been described only in the freshwater fishes Salmo gairdneri and Tilapia rendalli (Chliamovitch and Kuhn, 1977).

We developed a 3 week-long laboratory experiment designed to evaluate histopathological effects of environmental TBT levels on adult $C$. gigas and the recovery potential after oysters are returned to clean water.

\section{MATERIAL AND METHODS}

\section{General procedures}

Adults C. gigas were collected in Marennes-Oléron Bay, which is the main farming site of cup-shaped oysters in France. Once specimens were taken from the beds, the oysters were initially stored for over 15 days in land-based tanks and later allowed to acclimate for 4 days in the laboratory environment. They were then divided into four groups of 150 individuals homogeneous in size: individual mean weight for each group ranged from 52 to $64 \mathrm{~g}$. Each group was held separately in a 2001 tank in a flow-through seawater system at ambient temperature $\left(18^{\circ} \mathrm{C}\right)$. The flow of filtered $(10 \mu \mathrm{m})$ natural seawater (salinity 29$30 \times 10^{-3}$ ) was $40 \mathrm{l} / \mathrm{h}$ and food (diatoms) as well as oxygen were artificially supplied.

TBT fluoride (Fluka) dissolved in ethanol was delivered by a peristaltic pump. All glassware and teflon tubing were previously acid washed and kept in the dark during the assay to prevent any TBT photolysis. TBT concentrations in the water of each tank were checked every 2 days using the analytical method described by Michel (1987) (hydride generation/ Atomic Absorption Spectrometry). During the experiment, the mean concentrations in experimental tanks were $64.8 \quad(\mathrm{SD}=5) ; 13.1 \quad(\mathrm{SD}=2) \quad$ and $2 \mathrm{ng} / \mathrm{l}$ $(\mathrm{SD}=0.5)$; the control tank was below the detection limit $(1 \mathrm{ng} / \mathrm{l})$. TBT degradation products, dibutyltin or monobutyltin, were below the detection limit (0.5 ng/l).

Animals were kept in contaminated tanks during 18 days (contamination phase) and then held for 21 days in clean water (depuration phase). Every 3 days, five oysters were sampled from the low and medium concentration groups, in order to analyse the TBT content in their tissues. At days $0,3,10,13$ corresponding to the contamination phase, and 6,14 and 20 of the depuration phase, five live individuals from each group were sampled and fixed for histological examinations. Mortalities were recorded daily. Dead and sacrificed animals were checked for calcification anomalies of the shells (chambers).

\section{Histological procedure}

After breaking the ligament, the flat valve was lifted and the adductor muscle was cut, taking care not to damage the underlying body. Whole animals were immersed for 24 hours in pH 7.4 Carson's fixative $\left[\mathrm{NaH}_{2} \mathrm{PO}_{4}: 23.8 \mathrm{~g} ; \mathrm{NaOH}: 5 \mathrm{~g}\right.$; distilled water: $900 \mathrm{ml} ; 40 \%$ formalin, filtered, $100 \mathrm{ml}$, according to Pearse (1980)]. Two cross sections were then made, in order to permit examination of the stomach, intestine, digestive diverticula, gills, mantle, gonad, and kidney. Tissues were left for another 24 hours in a fixative, dehydrated with ethanol, cleared with xylene and embedded in paraffin. Sections $(3 \mu \mathrm{m})$ were cut, and stained with Ehrlich's hematoxylin and eosin (EHE) for general examination and with periodic acid-Schiff (PAS) for glycogen and mucopolysaccharide evaluation.

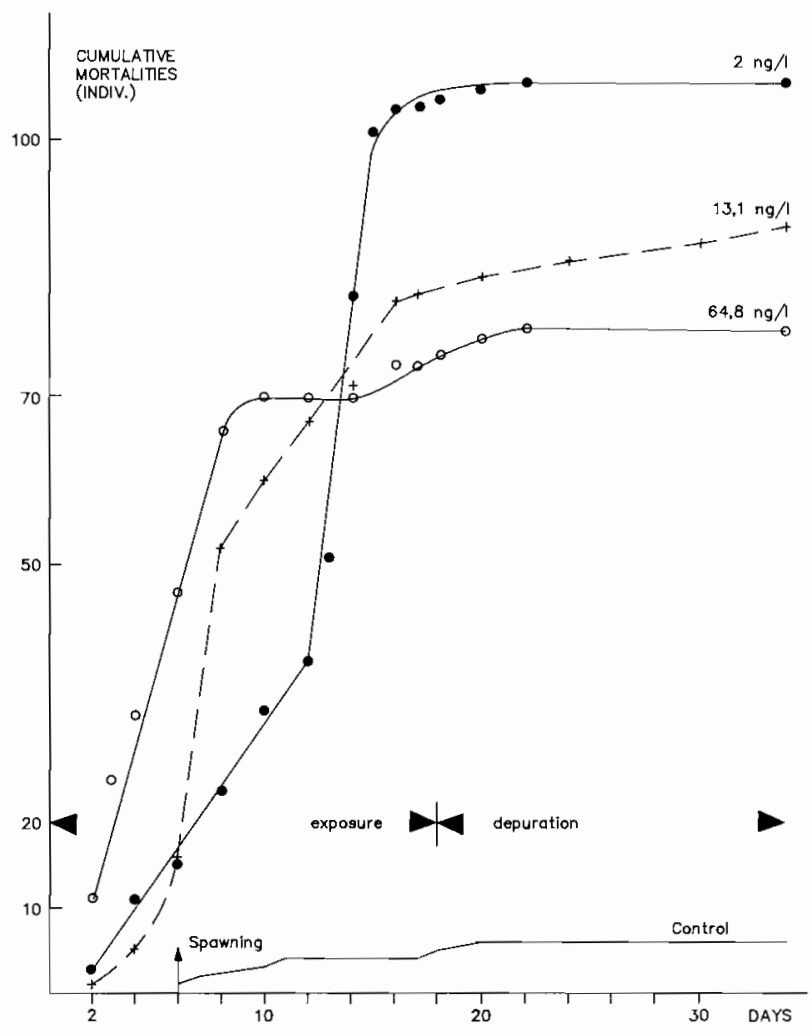

Figure 1. - Cumulative mortalities during the experiment.

\section{RESULTS}

\section{Mortalities}

The observed cumulative mortalities are presented in figure 1. In each one of the treated groups, mortality was high when compared to the control group. Up to treatment day 13 , it was roughly dose-dependent, but occurred regardless of TBT concentration from day 13 to day 18 . It should be mentioned that some oysters began to spawn at day 6 , which might indicate a reproduction-linked individual variability in response to TBT. 


\begin{tabular}{|c|c|c|c|c|c|c|c|}
\hline \multirow{2}{*}{ 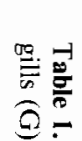 } & \multirow{2}{*}{$\begin{array}{c}\text { Days } \\
\text { of } \\
\text { experiment }\end{array}$} & \multicolumn{3}{|c|}{ Contamination phase } & \multicolumn{3}{|c|}{ Depuration phase } \\
\hline & & 3 & 10 & 13 & 6 & 14 & 20 \\
\hline 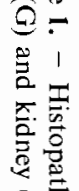 & $\begin{array}{l}\text { TBTF ng/l } \\
\quad 2\end{array}$ & No effect & $\begin{array}{l}\text { VCT moderate increase in } \\
\text { hemocyte number in } \\
\text { blood sinuses. }\end{array}$ & $\begin{array}{l}\text { DD/CD some tubules are } \\
\text { flattened, weak PAS } \\
\text { positivity. } \\
\text { VCT hemocytic infiltra- } \\
\text { tion still moderate. }\end{array}$ & $\begin{array}{l}\text { Digestive gland returns to } \\
\text { normal. }\end{array}$ & - & - \\
\hline 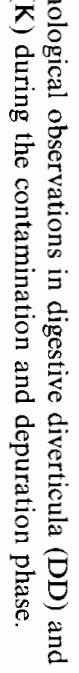 & 13.1 & No effect & $\begin{array}{l}\mathrm{DD} / \mathrm{CD} \text { fragmentation of } \\
\text { apical cytoplasm in } \\
\text { some digestive tubules. } \\
\text { PAS positivity reduced. } \\
\text { VCT infiltration of hem- } \\
\text { olymph spaces by } \\
\text { numerous hemocytes } \\
\text { and "brown cells". }\end{array}$ & $\begin{array}{l}\text { DD/CD general decrease } \\
\text { in height of epithelia } \\
\text { digestive tubules, } \\
\text { cuboïdal cells present- } \\
\text { ing large unstained } \\
\text { empty vacuoles and } \\
\text { dilated lumen, some } \\
\text { necrotic tubules. } \\
\text { vCT strong decay in PAS } \\
\text { positivity (fig. 2.10) } \\
\text { hemocytosis in blood } \\
\text { spaces increased. } \\
\text { G. vacuolated cells. } \\
\text { mucous cells staining } \\
\text { faint, erosion of frontal } \\
\text { cells in some filaments } \\
\text { acidophilic cells unaf- } \\
\text { fected. } \\
\text { K. swelling of epithalial } \\
\text { cells, erosion of apical } \\
\text { cytoplasm - no signs of } \\
\text { necrosis. }\end{array}$ & $\begin{array}{l}\text { Repair pattern basically th } \\
(64.8 \mu \mathrm{g} / \mathrm{l}) \text {. }\end{array}$ & e same as in oysters expose & ed to higher concentration \\
\hline 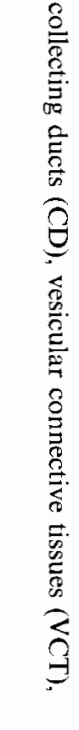 & 64.8 & $\begin{array}{l}\text { DD/CD pale staining of } \\
\text { digestive cells with } \\
\text { EHE some with apical } \\
\text { cytoplasm fragmenta- } \\
\text { tion, acidophilic cell } \\
\text { debris in lumen (fig. } \\
2.2 \text { ). } \\
\text { PAS positivity reduced in } \\
\text { digestive and branchial } \\
\text { cells (fig. } 2.13 \text { ). }\end{array}$ & $\begin{array}{l}\text { DD/CD apical fragment- } \\
\text { ation increased. } \\
\text { cuboïdal aspect of some } \\
\text { digestive cells, lumen } \\
\text { empty and dilated. } \\
\text { basal part retained, } \\
\text { crypt cells unaffected } \\
\text { (fig. } 2.5 \text { ). PAS positiv- } \\
\text { ity strongly reduced } \\
\text { (fig. } 2.4 \text { ). } \\
\text { VCT hemolymph spaces } \\
\text { moderately infiltrated } \\
\text { with hemocytes and } \\
\text { brown cells, Leydig } \\
\text { cells: PAS positivity } \\
\text { strongly decreased. } \\
\text { G. high vacuolization, } \\
\text { spongy cytoplasm, } \\
\text { weak PAS positivity. }\end{array}$ & $\begin{array}{l}\text { DD/CD necrosis of diges- } \\
\text { tive epithelial cells (fig. } \\
2.6 \text { ), basal lamina rup- } \\
\text { tured in some tubules. } \\
\text { VCT hemolymph spaces } \\
\text { heavily infiltrated with } \\
\text { hemocytes (fig. 2.8), } \\
\text { increased number of } \\
\text { brown cells. } \\
\text { G. general decrease stain- } \\
\text { ing of mucous and } \\
\text { acidophilic cells break } \\
\text { off of frontal and lat- } \\
\text { eral cilia. apical erosion } \\
\text { of cytoplasm of frontal } \\
\text { cells (fig. 2.12). } \\
\text { K. hypertrophy of } \\
\text { epithelia of nephridial } \\
\text { tubes. cells with small } \\
\text { acidophilic granul- } \\
\text { ations and apical swell- } \\
\text { ing. some tubules } \\
\text { necrotic, hemocytes in } \\
\text { the lumen (fig. 2. } 16 \text { ). }\end{array}$ & $\begin{array}{l}\mathrm{DD} / \mathrm{CD} \text { some digestive } \\
\text { tubules lined by strong } \\
\text { basiphilic cells-o- } \\
\text { thers still necrotic. } \\
\text { VCT heavy hemocytic } \\
\text { infiltration tendency of } \\
\text { pigmented granules of } \\
\text { brown cells to fusc. } \\
\text { G. epithelial cells remain } \\
\text { vacuolated - normal } \\
\text { staining of mucous and } \\
\text { acidophilic cells. } \\
\text { K. epithelia remain swol- } \\
\text { len-heavy accumula- } \\
\text { tion of }+1-\text { pycnotic } \\
\text { hemocytes in the } \\
\text { lumen. }\end{array}$ & $\begin{array}{l}\text { Tissue appearance returns } \\
\text { normal (fig. 2.17) } \\
\text { except vacuolization of } \\
\text { gill epithelia (fig. } 2.18 \text { ) } \\
\text { and hemocytosis (fig. } \\
\text { 2. 19). }\end{array}$ & $\begin{array}{l}\text { No evolution compared } \\
\text { to day } 14 .\end{array}$ \\
\hline
\end{tabular}


Figure 2. - TBT-induced cell injury in target tissues.

2. 1. Ehrlich's hematoxylin eosin (EHE). Control digestive gland (contamination phase, day 13).

$\mathrm{DD}=$ digestive diverticula.

$\mathrm{DC}=$ digestive cell.

$\mathrm{SC}=$ secrctory cell.

\subsection{EHE.}

$64.8 \mathrm{ng} / 1 \mathrm{TBT}-$ treated digestive gland (contamination phase. day 3 ).

Apical cytoplasm fragmentation (AF).

\subsection{Periodic acid-Schiff (PAS).}

Control digestive gland (contamination phase, day 3 ).

$\mathrm{DD}=$ digestive diverticula

$\mathrm{CD}=$ collecting ducts.

Arrows indicate PAS - positive granules.

\subsection{PAS.}

$64.8 \mathrm{ng} / 1$ TBT-treated digestive gland (contamination phase. day 10).

No PAS positivity in digestive cells (arrows).
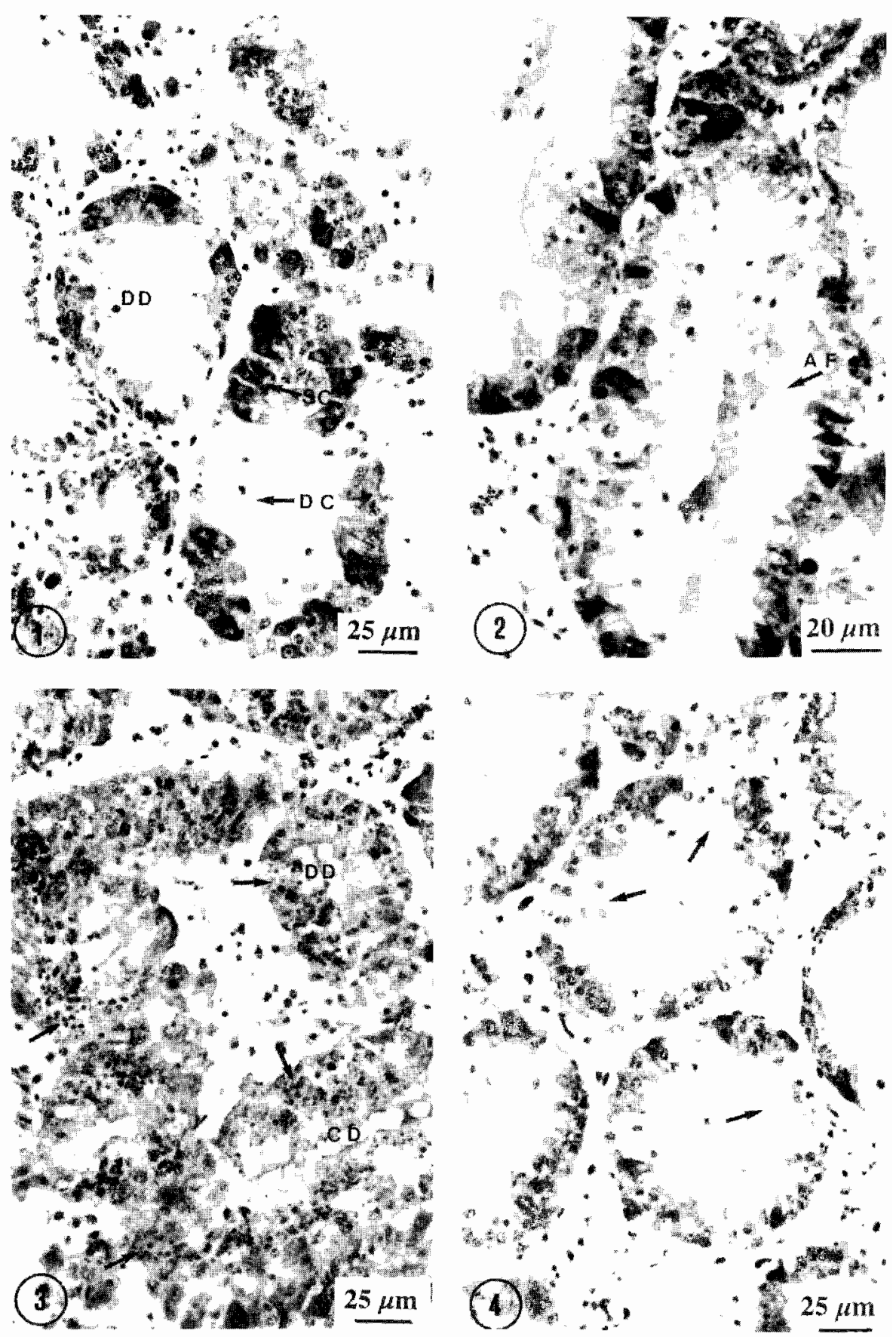

It is well known that the spawning period corresponds to a phase of increased mollusc sensitivity to changes in the environment (salinity, oxygen, toxicity...). In our experiment, mortalities appeared in the control group from the first day of spawning and remained thereafter at a very low level. Conversely, in the case of TBT-exposed specimens, mortalities were observed as early as the first days and increased significantly following spawning. This enables us to regard the observed mortalities as attributable to TBT action and not to any experimental artifacts.

\section{Bioaccumulation}

During the accumulation phase, a plateau of TBT contamination was not reached by any of the analysed groups. However, during this period, TBT content in tissue increased from $6.5 \mathrm{ng} / \mathrm{g}$ dry weight to 12.6 and $49.8 \mathrm{ng} / \mathrm{g}$ respectively for exposures of 2 and $13.1 \mathrm{ng} / \mathrm{l}$. At the end of the depuration phase, levels were 7.3 and $27.7 \mathrm{ng} / \mathrm{g}$, showing a slow elimination rate. Comparatively, contamination of the control groups remained constant during both phases: mean value $4.6 \pm 0.8 \mathrm{ng} / \mathrm{g}$. Dibutyltin was the major degradation 


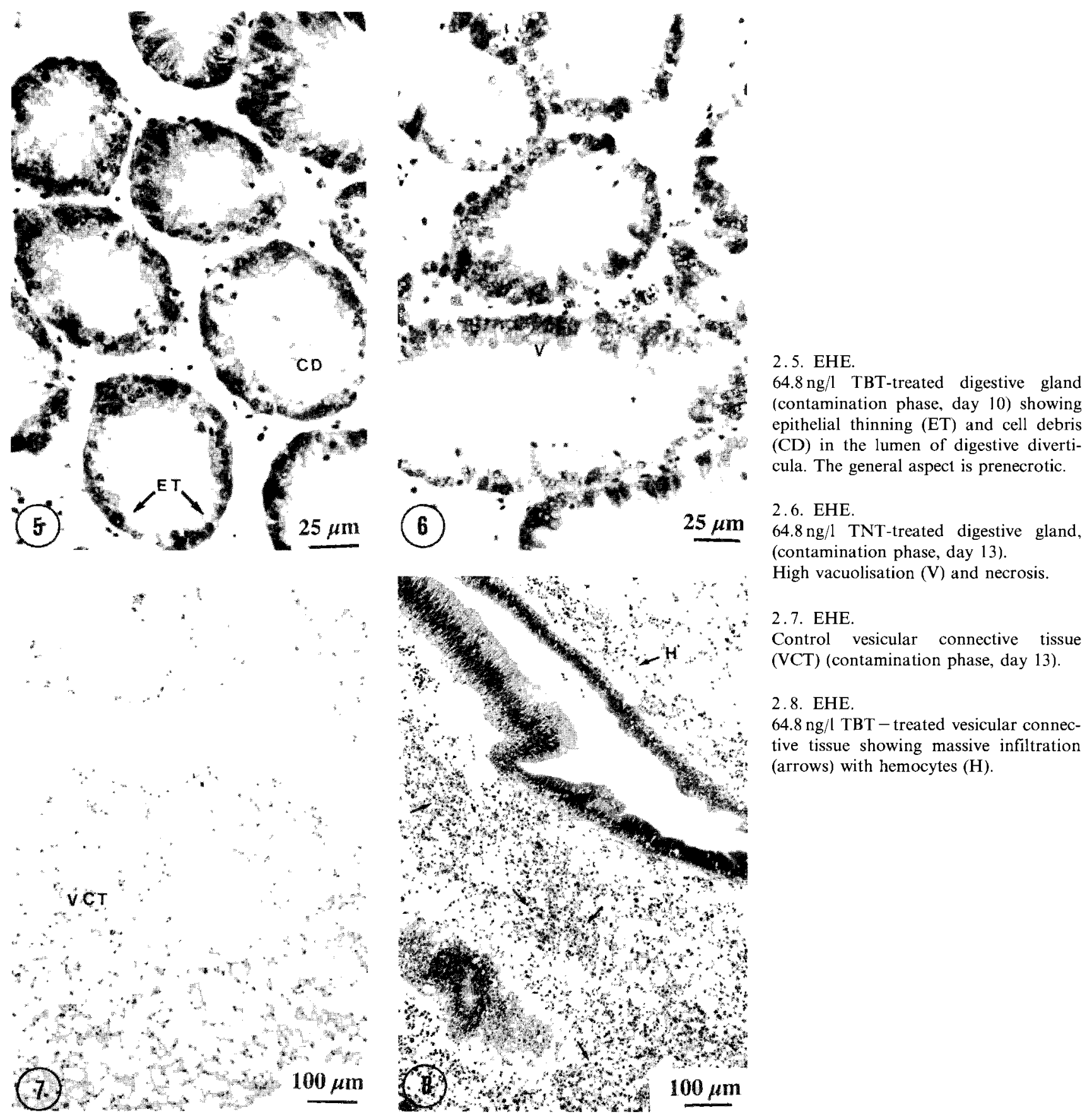

product measured in tissues; its concentration increased sharply during the exposure period and then decreased slowly. Thus for the group exposed to $13.1 \mathrm{ng} / 1$ of TBT, DBT contamination which had risen from $2.8 \mathrm{ng} / \mathrm{g}$ dry weight to $35.6 \mathrm{ng} / \mathrm{g}$ during the exposure phase, remained very high even after 21 days of depuration $(26.7 \mathrm{ng} / \mathrm{g}$ dry weight).

\section{Histological observations}

Detailed results are presented in table I which shows the histopathological changes recorded for each group, at specific time intervals for each target organ. Pathological effects were roughly similar in the different groups treated, but the time sequence and the severity of injury differed. No histopathological effect was observed in the control animals during the experiment: see figures $2.1,2.3,2.7,2.9,2.11,2.14$ and 2.15 .

\section{Shell malformations}

Shell chamber formation was not observed during the accumulation phase, and none of the control 
2.9. PAS

Control VCT (contamination phase, day 10).

$\mathrm{VC}=$ vesicular cells, arrows show PAS- positive glycogen storage areas.

\section{10. PAS.}

$13.1 \mathrm{ng} / \mathrm{l} \mathrm{TBT}$ - treated VCT (contamination phase, day 10).

Glycogen content is strongly reduced (arrows)

\subsection{EHE}

Control branchial filaments (contamination phase, day 13 ).

$\mathrm{AC}=$ acidophilic cell.

$\mathrm{MC}=$ mucous cell

$\mathrm{ACi}=$ Apical cilia

\section{12. EHE}

$64.8 \mathrm{ng} / \mathrm{l} \mathrm{TBT}-$ treated gills (contamination phase, day 13).

Filaments show apical erosion (AE) and loss of cilia (LCi). Faint staining of acidophilic cells (AC). No evidence of any mucous cells.
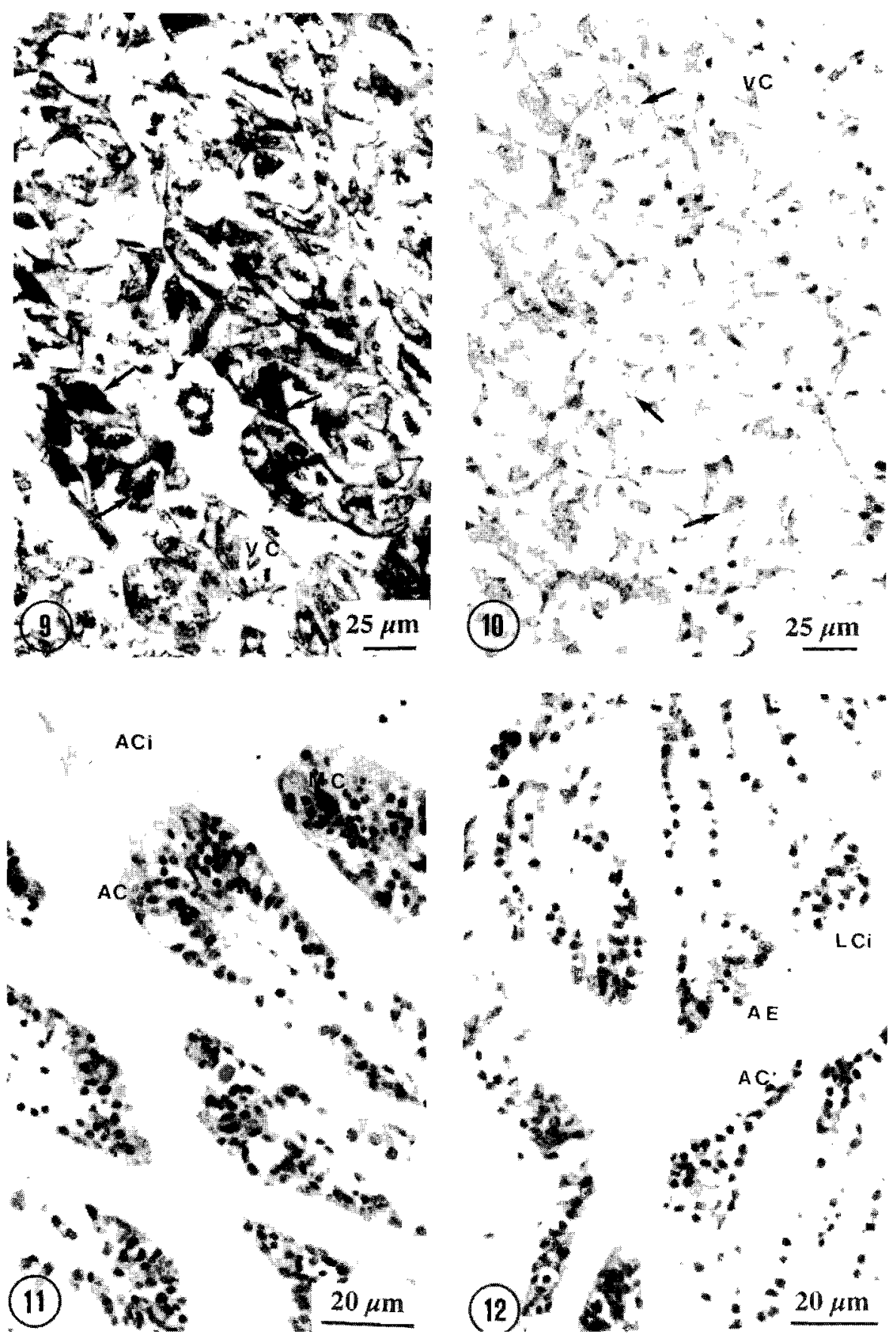

animals had chambers during the two experimental phases. However, 7 of the 15 animals sacrificed during the depuration phase presented this abnormality in the $64.8 \mathrm{ng} / 1$ treated group, compared to one in the $13.1 \mathrm{ng} / 1$ group and none in the $2 \mathrm{ng}$ TBTF/ 1 group. Nevertheless, in a separate assay, where TBT concentrations varied between 2 and less than $2 \mathrm{ng} / \mathrm{l}$, anomalies in calcification were observed in a significant number of individuals $(13 \%)$.

\section{DISCUSSION}

The present report provides evidence for TBT-induced cell injury in defined target tissues of the Pacific oyster $C$. gigas, such as digestive diverticula, gills, vesicular connective tissue, hemal tissue and kidney. Although the observed histopathological changes cannot be linked with the relatively high mortalities observed during exposure and probably due to spawning, their severity appears to be both dose and time- 

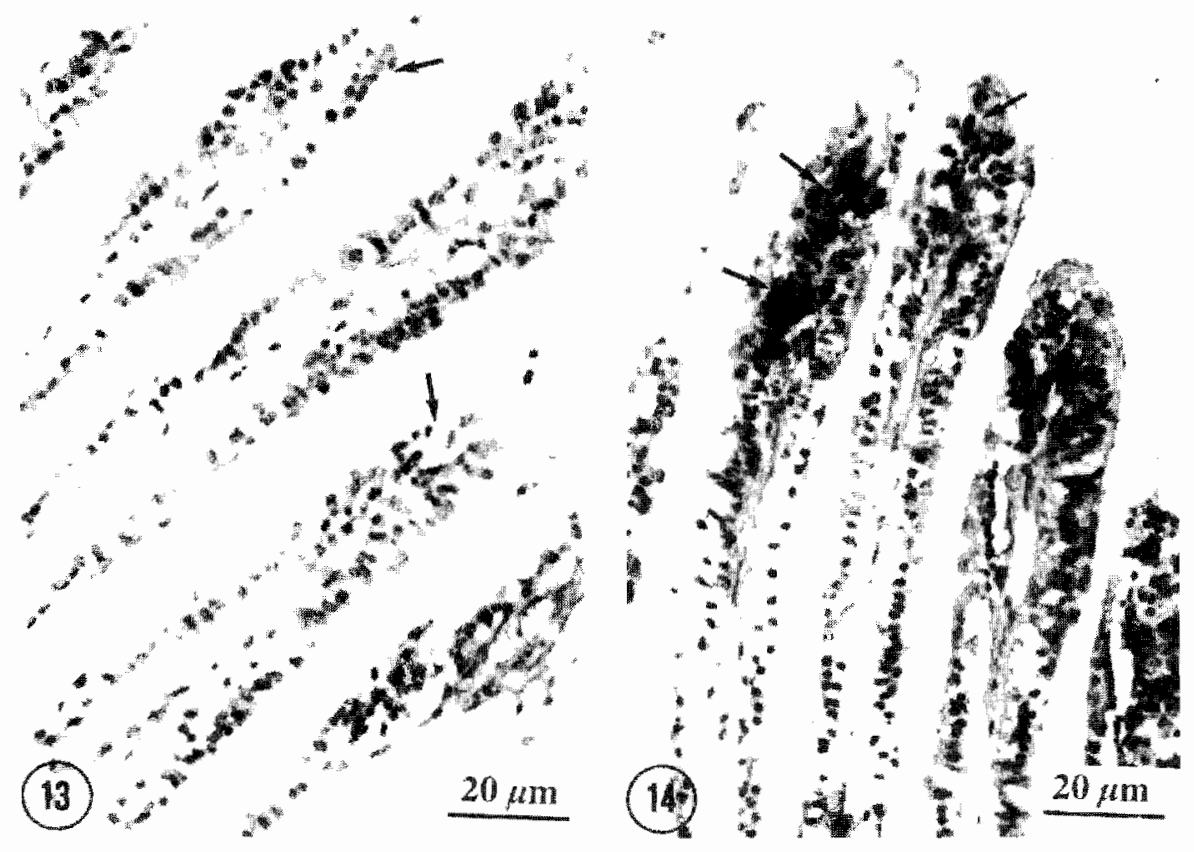

2. 13. PAS

$64.8 \mathrm{ng} / 1$ TBT-treated gill filaments (contamination phase, day 3). Absence of PAS-positive mucous cells (arrows).

2. 14. PAS.

Control gill filaments (contamination phase, day 3) showing numerous PAS - positive areas, mostly representing mucous cells (arrows)

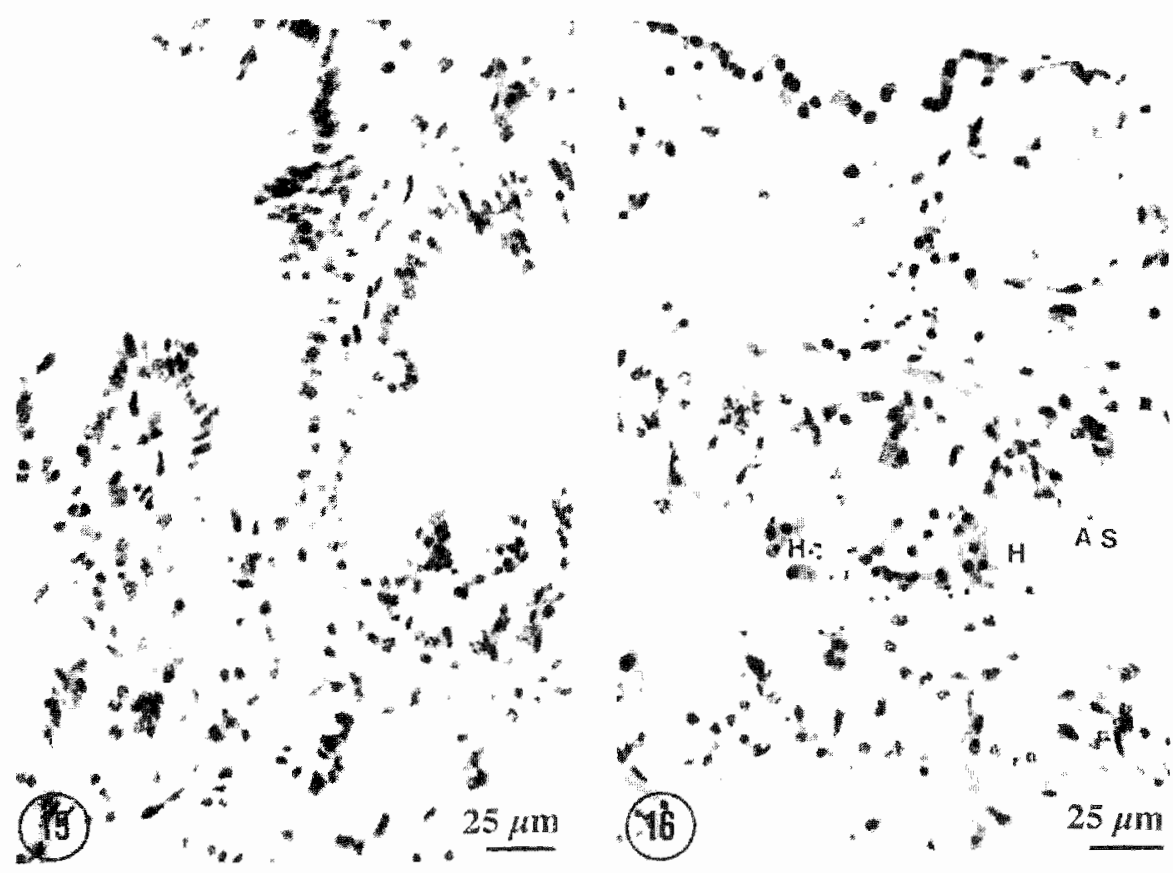

2. 15. EHE.

Control kidney (contamination phase. day 13).

\subsection{EHE.}

$64.8 \mathrm{ng} / 1$ TNT - treated kidney (contamination phase, day 13). Epithelial cells show apical swelling (AS) and necrosis. The lumen contains hemocytes $(\mathrm{H})$.

dependent. Furthermore, the data acquired suggest that poisoning results from different mechanisms.

Although there are few studies devoted to histopathological effects of pollutants in marine molluscan species, digestive diverticula modifications such as intensive fragmentation. vacuolization, epithelial thinning have been noted (Tripp et al., 1984; Couch, 1984; Rasmussen, 1982; Rasmussen et al., 1985). Such modifications could be considered as a general molluscan response to stress (Moore et al., 1979; Lowe et al., 1981) and have been interpreted as a physiological survival mechanism of bivalves subjected to stress (Moore et al., 1979; Henry, 1987). This hypothesis is consistent with the observed rapid regeneration capacity of the organ. However limited necrosis, indicative of a degenerative syndrome was also conspicuous in digestive cells, and longer exposure might have led to extensive and irreversible breakdown, by affecting the potential regenerative cells of the crypts. Digestive cells appear to be the first ones affected on a structural scale. However, an ultrastructural study will be required to determine whether they are truly 

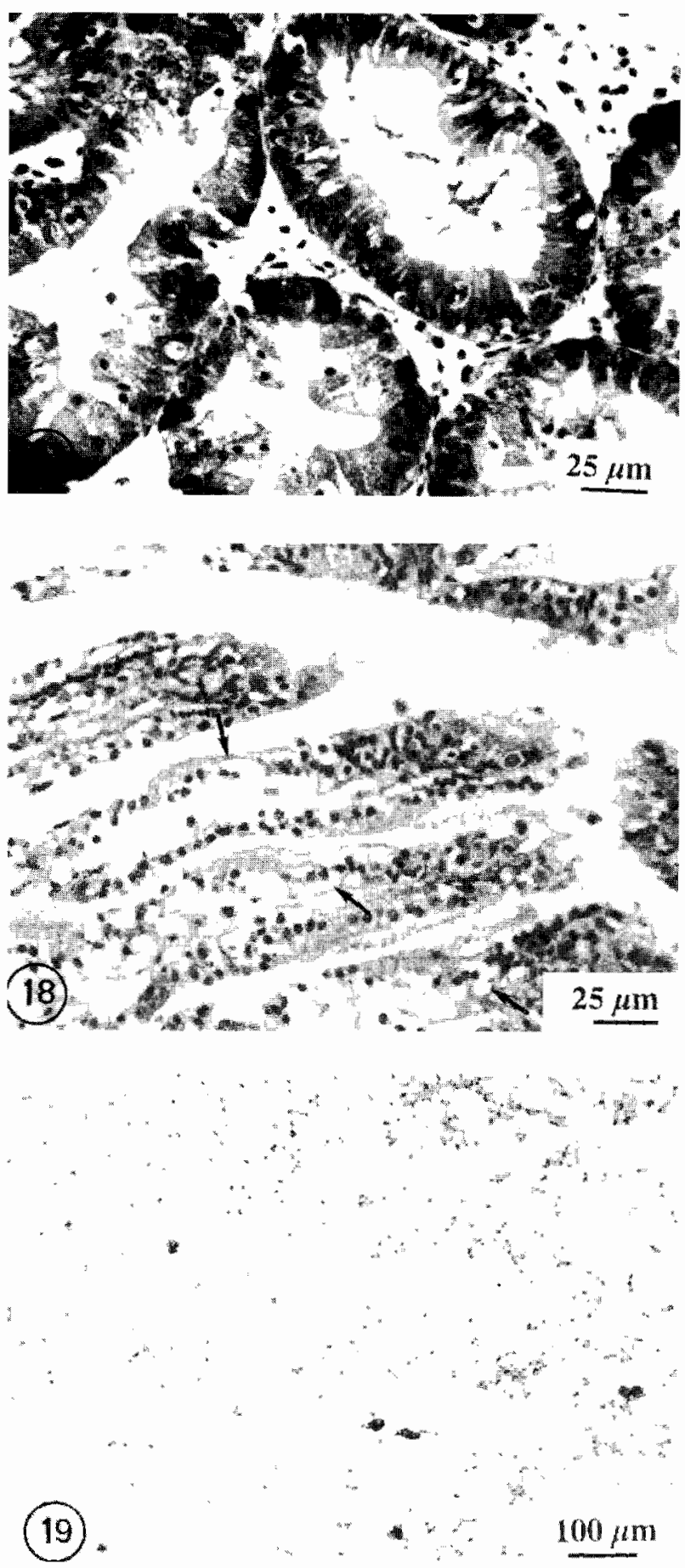

2.17. EHE.

$64.8 \mathrm{ng} / 1$ TBT - treated digestive gland (depuration phase, day 14) - aspect normal.

2.18. EHE.

$64.8 \mathrm{ng} / \mathrm{I} \mathrm{TBT}$ - Ireated gills (depuration phase, day 14 ) - vacuolisation still present (arrows) and cilia losi in apical part of some filaments.

2. 19. EHE.

$64.8 \mathrm{ng} / 1$ TBT - treated VCT (depuration phase, day 14) - hemocytic infillration still present. the primary targets or whether secretory cells are more sensitive, as observed by Henry and Carles (1985) for other toxicants.

Most environmental contaminants cause gill damage in exposed aquatic animals (Meyers and Hendricks, 1982). Chliamovitch and Kuhn (1977) observed gill lesions in $S$. gairdneri poisoned by TBTO, but no alterations were found in the same species after TBTCl poisoning. Our study in $C$. gigas shows gills to be affected on exposure to TBTF. Degenerative changes were indicated by loss of cytoplasmic density and vacuolization in all cells of the filament. Advanced necrotic changes were evident in 64.8 and $13.1 \mathrm{ng} / \mathrm{l}$-exposed oysters at treatment day 13 . Whether or not loss of cilia accompanies general autolysis, or constitutes a specific lesion, is difficult to ascertain. However, gill injury may be considered to severely impair feeding. gas exchanges and osmoregulation. No mucous hypersecretion was observed. Instead, hyposecretion occurred, which can be interpreted either as a side effect of the pre-necrotic phase or as a TBT-induced inhibition of mucous synthesis.

A strong decrease of PAS positivity was noticed in branchial and digestive cells, as well as in the main glycogen storage cells, i.e. the vesicular cells of the connective tissue. Reduced glycogen storage has been noted in carp and in S. gairdneri (Thompson et al., 1985). Glycogen breakdown could arise from the inhibitory effect of triorganotin compounds on mitochondrial energy conservation (Thompson et al., 1985).

Other effects in C. gigas include hemocytic and "brown cells" infiltration and kidney hypertrophy, which we feel could be discussed together. The hemocytes of molluses have various physiological functions including metal storage (Ruddell and Rains, 1975; George et al. 1978; Cheng, 1981; Simkiss and Mason, 1983). It may be possible that hemocytes remove metals from the hemolymph, thereby keeping blood concentration below toxic level. In addition, they could take the compounds expelled in the basal lamina of digestive and branchial epithelia and transfer them to the kidney (Ballan-Dufrançais et al. 1985). Bivalve "brown cells" or serous cells are similar to gastropod pore cells (Martoja et al.. 1985) and originate from pericardial glands (Cheng, 1981). Although they do not concentrate silver as sulfide in C. gigas, they do concentrate this compound in Pecten maximus (Martoja et al., 1985). The physiology of the excretory system in bivalves is largely unknown. but numerous studies have shown evidence for concentration of metals in the kidney (Simkiss and Mason, 1983). Herwig and Holwerda (1986) have demonstrated the accumulation of DBTCl in kidney cells of the freshwater mussel Anodonta anatina. Lack of extensive kidney damage, presence of hemocytes in the lumen of renal tubules, a presumed "throwing up" (Owen, 1972), accumulation of hemocytes and brown cells in blood spaces and under basal lamina could all indicate an extensive detoxifying process. It 
is worth mentioning that tissue recovery was relatively slow at medium and high dose, with gill vacuolation and hemocytosis persisting as long as 20 days after poisoning.

No damage was detected under the light microscope in the mantle epithelia. However, normal metabolism was affected as assessed by chamber formation, due to abnormal conchiolin secretion. This could confirm Krampitz experiments (Krampitz et al., 1983) establishing that abnormal protein secretion is caused by the perturbation of molecular genetic mechanisms.

\section{CONCLUSION}

Observations of shell malformations lead us to consider that the threshold limit for induction of chambers in $C$. gigas shells should be roughly $2 \mathrm{ng} / \mathrm{l}$. This value is consistent with the field observations on Arcachon Bay oysters, showing anomalies in areas where TBT contamination was in the range of less than 2 to $5 \mathrm{ng} / 1$ (Alzieu et al., 1989).

Our results confirm the extreme harmfuiness of TBT for adult Pacific oyster $C$. gigas. Histological modifications on the cells of digestive diverticula, the primary target organ, are observed when oysters are exposed to concentrations as low as $2 \mathrm{ng} / \mathrm{l}$. This contamination is now considered as a usual level in wellflushed mariculture areas of the French Atlantic coast. Nevertheless, in case of exposure up to 2 weeks, tissues will regain their normal aspect within 6 days. In contrast, cell damage is more severe after 2 weeks of exposure at $13.1 \mathrm{ng} / 1$, a contamination level occasionally found in certain mariculture area. In this case, gill epithelia do not recover even after 20 days following the end of exposure. Assuming that severe digestive and gill cell injuries could have a negative effect on oyster metabolism, and considering the probable threshold for shell malformations, our data strongly suggest that safe TBT levels in the waters of oyster culture areas should be lower than $2 \mathrm{ng} / 1$.

\section{REFERENCES}

Alzieu Cl., J. Sanjuan, P. Michel, N. Borel, J. P. Dréno, 1989. Monitoring and assessment of butyltins in atlantic coastal waters. Mar. Poll. Bull., 20, 1, 22-26.

Ballan-Dufrançais C., A. Y. Jeantet, C. Feghali, S. Halpern, 1985. Physiological features of heavy metal storage in bivalve digestive cells and amoebocytes: EPMA and factor analysis of correspondances. Biol. Cell., 53, 283-292.

Cheng T. C., 1981. Bivalves. In: N. A. Rateliffe, A. F. Rowley Eds., "Invertebrate blood cells". Academic Press, London, 233-300.

Chliamovitch Y. P., C. Kuhn, 1977. Behavioural, hematological and histological studies on acute toxicity of bis, tri-n butyltin oxide on Salmo gairdneri Richardson and Tilapia rendalli Boulenger. J. Fish. Biol., 10, 575-585.
Couch J. A., 1984. Atrophy of diverticular epithelium as an indicator of environmental irritants in the oyster Crassostrea virginica. Mar. Environ. Res., 14, 525-526.

Gendron F., 1985. Recherches sur la toxicité des pcintures à base d'organostanniques et de l'oxyde de tributylétain vis-à-vis de l'huître Crassostrea gigas. Thèse dr. essciences Univ. Aix-Marseille.

George S. G., B. J. S. Pirie, T. L. Coombs, P. T. Grant, 1978. Detoxication of metals by marine bivalves: an ultrastructural study of the compartmentation of copper and zinc. in the oyster Ostrea edulis. Mar. Biol., 45, 147-156.

Gibbs P. E., G. W. Bryan, 1986. Reproductive failure in populations of the dog-whelk, Nucella lapillus, caused by imposex induced by tributyltin from antifouling paints. J. Mar. Biol. Ass. U.K., 66, 7667-7677.

Henry M.. D. Carles, 1985. Sensitivity to pollutants of the secretory cell in the digestive gland of the marine bivalves. IIIrd. Intern. Symp. on responses of marine organisms to pollutants. Plymouth, 1985.

Henry M., 1987. La glande digestive de la palourde Ruditapes decussatus L. Recherches ultrastructurales, cytochimiques, écophysiologiques et écotoxicologiques. Thèse dr. es-sciences, Univ. Aix-Marscille, 439 p.

Herwig H. J.. D. A. Holwerda, 1986. Cytochemical localization of tin in freshwater mussels exposed to Di-n-butyltin dichloride. Aquat. Toxicol., 9, 117-128.

His E., R. Robert, 1983-1985. Développement des véligères de Crassostrea gigas dans le bassin d'Arcachon; études sur les mortalités larvaires. Rev. Trav. Inst. Pêches marit., 47, 1-2, 63-88

Krampitz G., H. Drolshagen, J. P. Deltreil, 1983. Soluble matrix components in malformed oyster shells. Experientia, 39, 1 105-1106.

Lowe D. M., M. N. Moore, K. R. Clarke, 1981. Effects of oil on digestive cells in musscls: quantitative alterations in cellular and lysosomal structure. Aquat. Toxicol., 1, 213-226

Martoja M., J. M. Bouquegneau, M. Truchet, R. Martoja, 1985. Recherche de l'argent chez quelques mollusques marins, dulcicoles et terrestres. Formes chimiques et localisation histologique. Vie et Milieu., 35, 1-13.

Mcyers T. R., J. D. Hendricks, 1982. A summary of tissue lesions in aquatic animals induced by controlled exposures to environmental contaminants, chemotherapeutic agents, and potential carcinogens. Mar. Fish. Review, 44, $1-\mathrm{I} 7$.

Michel P., 1987. Automatization of a hydride generation/A.A.S. system-an improvement for organotin analysis. In: Oceans'87 Proceedings. 4, Organotin Symposium, 1340-1343. Halifax, Canada.

Moore M. N., D. M. Lowe, S. L. Moore, 1979. Induction of lysosomal destabilization in marine bivalve molluses exposed to air. Mar. Biol. Letters, 1, 47-57.

Owen G., 1972. Lysosomes, peroxisomes and bivalves. Science Progress., 60, 299-318.

Pearse A. G. E., 1980. The chemistry and practice of fixation. In: A. G. E. Pearse ed., "Histochemistry". Churchill Livingstone, Edinburgh, 1, 97-158.

Vol. 3, ño $2-1990$ 
Rasmussen L., 1982. Light microscopical studies of the acute toxic effects of $\mathrm{N}$-Nitrosodimethylamine on the marine mussel Mytilus edulis. J. Invertebr. Pathol., 39. 66-80.

Rasmussen L. P. D., Hage E., Karlog O., 1985. Light and clectronmicroscopic of the acule and long-term toxic effects of $\mathrm{N}$-nitrosodipropylamine and $\mathrm{N}$-methylnitrosurea on the marine mussel Mytilus edulis. Mar. Biol., 85, 55-65.

Ruddell C. L., D. W. Rains, 1975. The relationship betwecn zinc, copper and the basophils of two Crassostrcid oysters, Crassostrea gigas and Crassostrea virginica. Comp. Biochem. Physiol., 51A, 565-591.
Simkiss K., A. Z. Mason, 1983. Metal ions: metabolic and toxic effects. In: K. M. Wilbur ed. "The Mollusea", 2 , Academic Press, Paris, 101-164.

Thompson J. A., M. G. Scheffer, R. C. Picrce, Y. K. Chau, J. J. Cooney, W. R. Cullen, R. J. Maguire, 1985. Organotin compounds in the aquatic environment scientific critcria for assessing their effects on environmental quality. National Research Council, Canada, NRCC $n^{\circ} 22494$.

Tripp M. R., C. R. Fries, M. A. Craven, C. E. Grier, C. E. Gates, 1984. Histopathology of Mercenaria mercenaria as an indicator of pollutant stress. Mar. Environ. Res., 14, 521-524. 